\title{
Biomarkers for early detection of acute kidney injury
}

\author{
This article was published in the following Dove Press journal: \\ Current Biomarker Findings \\ 28 September 2012 \\ Number of times this article has been viewed
}

\section{Won K Han \\ Department of Medicine, Division of Nephrology, Thomas Jefferson University Hospital, Philadelphia, PA, USA}

Correspondence: Won K Han Thomas Jefferson University, Division of Nephrology, 833 Chestnut Street, Suite 700, Philadelphia, PA 19107, USA Tel + I 2I59558826

Fax + I 2155034099

Email won.han@jefferson.edu
Abstract: It is very difficult to make an early diagnosis of acute kidney injury (AKI) using serum creatinine, which is the standard metric tool for the detection of renal injury. The absence of sensitive AKI biomarkers has impaired progress in the nephrology field and had a detrimental effect on the design and outcome of AKI clinical trials. Recently, several proteins have shown potential in the early detection of AKI, including neutrophil gelatinase-associated lipocalin, kidney injury molecule-1, and interleukin-18. This review discusses the current status of three AKI biomarkers as a potential diagnostic tool for the early detection of AKI. The focus is limited to prospective human studies from January 2005 to December 2011. The review compares the clinical conditions for which the AKI biomarkers have the greatest potential utility for the early detection of AKI. It also demonstrates the barriers to the successful use of AKI biomarkers in clinical practice, as well as the future trials that will be needed to validate their use. Despite the early promise of biomarkers such as neutrophil gelatinase-associated lipocalin, kidney injury molecule-1, and interleukin-18 for the early detection of AKI, none of these biomarkers has demonstrated a clear benefit in detecting various types of AKI in daily clinical practice. Indeed, the majority of published clinical studies of known AKI biomarkers so far are small and insufficient to support clinical studies of AKI biomarkers as an effective early AKI diagnostic test in humans.

Keywords: acute kidney injury, biomarker, early detection

\section{Introduction}

\section{Acute kidney injury}

Acute kidney injury (AKI) is a heterogeneous entity associated with various clinical presentations, treatments, and procedures. It represents a clinical situation that can vary from subclinical renal injury, in which serum creatinine ( $\mathrm{SCr}$ ) changes minimally, to severe oliguric renal injury associated with tubular necrosis with failure of function. AKI is often found in the setting of multiple organ failures and sepsis, and is an important cause of morbidity and mortality in hospitalized patients. The main cause of hospital-acquired AKI is one or more events of ischemic insult and nephrotoxic injury to kidneys. The incidence of hospital-acquired AKI varies from 5\% in patients with normal renal function to $25 \%$ in intensive care unit (ICU) patients. ${ }^{1,2}$ Mortality rates of patients with postoperative AKI range from $50 \%$ to $70 \%$ among ICU patients who require renal replacement therapy (RRT). ${ }^{3,4}$ For the last 40 years, the mortality rate of patients with severe AKI requiring RRT in the ICU has not decreased significantly despite advances in supportive care, including continuous RRT. 


\section{Defining $A K I$ and the limitations of current AKI criteria}

There are more than 30 definitions for the diagnosis of AKI in published studies, most based on $\mathrm{SCr}$ values. The lack of a standard definition of AKI has had a detrimental effect on clinical trials in the diagnosis of AKI. Recently, two new definitions of AKI have been developed as the uniform standard for the diagnosis and classification of AKI: RIFLE (risk, injury, failure, loss, and end-stage renal disease) and AKIN (acute kidney injury network). ${ }^{5,6} \mathrm{It}$ is, however, a challenge to detect AKI in a timely fashion with current RIFLE and AKIN criteria since these definitions are entirely based on $\mathrm{SCr}$ increases or decreases in urine output. SCr is insensitive for the early detection of AKI because the change in $\mathrm{SCr}$ does not discriminate the time and type of renal insult or the site and extent of glomerular or tubular injury. ${ }^{7-9}$ Therefore, current AKI criteria do not allow for the early detection of AKI in a timely fashion so that intervention can be initiated. There is currently no standard definition for AKI that is not based on a change in SCr.

The lack of reliable biomarkers for the early detection of injury leads to delays in the introduction of treatment until well into the course of the renal injury. Previous animal studies clearly demonstrate that treatment must begin well before the rise of SCr and very early after the insult. ${ }^{10-14}$ Therefore, it is not surprising that many potential therapeutic agents show little success in human studies. ${ }^{15-19}$ There are currently no effective therapies available for the prevention and/or treatment of AKI. Dialysis remains the only FDA-approved treatment option for established AKI.

\section{New biomarkers under evaluation}

It has been postulated that introducing therapy early in the disease process would reduce the mortality rate associated with AKI. Several proteins and biochemical markers emerged as sensitive and specific biomarkers capable of the early detection of acute tubular injury through the application of functional genomics and proteomics to human and animal AKI models, and have proven to be promising biomarkers as indicators of renal injury in recent human studies. ${ }^{20-23}$ These biomarkers include neutrophil gelatinaseassociated lipocalin (NGAL), kidney injury molecule-1 (KIM-1), interleukin-18 (IL-18), cystatin C, and L-fatty acid binding protein.

Previous cross-sectional studies clearly established that new AKI biomarkers can differentiate patients with established AKI from patients without AKI. However, a cross-sectional study gives no indication of whether new AKI biomarkers are useful for the early detection and prognosis of AKI. Current AKI biomarker studies are past cross-sectional measurements unrelated to a clinically or biochemically defined end point. The inherent benefit of new AKI biomarkers is for making an early diagnosis of AKI that correlates with future declines in renal function as detected by changes in $\mathrm{SCr}$, not when $\mathrm{SCr}$ is already grossly elevated. The successful prediction of AKI at an early stage may allow potential therapies to be evaluated earlier, at a stage when they are more likely to be successful.

The author focuses this review on the current status of NGAL, KIM-1, and IL-18 as potential diagnostic tools for the early detection of AKI in prospective human clinical studies. A comprehensive review on promising AKI biomarkers is beyond the scope of this paper and can be found elsewhere. . $^{24,25}$

\section{Methods of quantitation and stability of urinary proteins}

Several methods have been used for the measurement of AKI biomarkers in published studies. Current quantification methods include enzyme-linked immunosorbent assay, microsphere-based Luminex assay, and nephelometry. In addition, the Triage NGAL device (Biostite Incorporated, San Diego, CA), ARCHITECT analyzer (Abbott Diagnostics, Abbott Park,IL), and KIM-1 RenaSticks (Argutus Medical, Dublin, Ireland) have been developed as point-of-care tests (POCs) for NGAL and KIM-1, respectively. ${ }^{26-28}$

The optimal methods for collecting, handling, and storing biological samples also need to be established as a necessary first step before testing the clinical utility of laboratory tests. Failure to do so may result in erroneous conclusions based on an extrinsic factor such as a compound's poor stability at room temperature and prolonged storage with repeated freeze-and-thaw cycles. Urinary NGAL (uNGAL) and KIM-1 (uKIM-1) proteins did not degrade significantly for up to 24 hours at $4{ }^{\circ} \mathrm{C}$ and at room temperature, and for up to 1 year in prolonged storage at $-80^{\circ} \mathrm{C}$ with repeated freeze-and-thaw cycles. ${ }^{29}$ Unpublished data indicate that urinary IL-18 (uIL-18) was stable for at least 4 hours at room temperature and for 24 hours at $4{ }^{\circ} \mathrm{C}$ (Table 1$)$. The addition of a protease inhibitor was not necessary to prevent the degradation of the uNGAL, uKIM-1, and UIL-18 proteins. Further studies are necessary to determine the stability of the various other AKI biomarkers in routine clinical storage conditions, including a number of freeze-thaw cycles. These findings are 
Table I Stability of urinary biomarkers

\begin{tabular}{|c|c|c|c|}
\hline \multirow[t]{2}{*}{$\begin{array}{l}\text { Collection and } \\
\text { processing }\end{array}$} & \multicolumn{3}{|c|}{$\begin{array}{l}\text { Mean percentage difference when compared } \\
\text { to immediate storage at }-80^{\circ} \mathrm{C}\end{array}$} \\
\hline & KIM-I $(n=I 2)$ & $\operatorname{NGAL}(n=\mid 2)$ & IL-I $8(n=8)$ \\
\hline At RM for $4 \mathrm{hrs}$ & -2.1 & -3.9 & -7.1 \\
\hline At RM for $24 \mathrm{hrs}$ & -7.2 & -11.9 & -80.2 \\
\hline At $4^{\circ} \mathrm{C}$ for $4 \mathrm{hrs}$ & -1.3 & +3.0 & -0.7 \\
\hline At $4^{\circ} \mathrm{C}$ for $24 \mathrm{hrs}$ & -3.3 & -2.5 & -1.3 \\
\hline PI vs no PI & 0.5 & -0.8 & +7.3 \\
\hline
\end{tabular}

Note: Immediate storage at $-80^{\circ} \mathrm{C}$, place urine samples at $-80^{\circ} \mathrm{C}$ within first 20 minutes after collection.

Abbreviations: IL-18, interleukin-18; KIM-I, kidney injury molecule-I; NGAL, neutrophil gelatinase-associated lipocalin; PI, protease inhibitor; RM, room temperature.

critical to continuing validation studies of potential tandem AKI biomarkers.

\section{Utility of AKI biomarkers for the early detection of AKI}

The following section discusses in detail the potential role of NGAL, KIM-1, and IL-18 as diagnostic tools for the early detection of AKI in prospective human clinical studies.

\section{Neutrophil gelatinase-associated lipocalin}

NGAL is a member of the lipocalin superfamily. Lipocalin family members are thought to transport a variety of ligands within a $\beta$-barreled calyx. ${ }^{30}$ The human form was originally identified as a $25-\mathrm{kDa}$ protein covalently bound to gelatinase from human neutrophils and found to be highly expressed in the early postischemic mouse and rat kidney. ${ }^{31}$ The expression of the NGAL protein is detected predominantly in proliferating cell nuclear antigen-positive proximal tubule cells. The major ligands for NGAL are siderophores, which are small, iron-binding molecules. Siderophores produced by eukaryotes participate in NGAL-mediated iron shuttling that is important to various cellular responses, including proliferation and differentiation. ${ }^{32}$

NGAL has been implicated as an early predictive biomarker of ischemic AKI in several small, prospective single-center studies in children undergoing open-heart surgery (Table 2). ${ }^{26,27,33,34} \mathrm{AKI}$ was defined as a $50 \%$ increase in SCr occurring 1-3 days after surgery. UNGAL and plasma NGAL (pNGAL) were increased within 2-6 hours of cardiopulmonary bypass (CPB) and preceded an increase in $\mathrm{SCr}$ by 1-3 days in children who subsequently developed AKI. The area under the receiver operating characteristic curve (AUC-ROC) was $>0.90$ for the $2-6$ hours following CPB. These studies demonstrated great NGAL performance in the early detection of AKI. However, patients with chronic kidney disease (CKD), diabetes mellitus, and peripheral vascular disease, which are common co-morbidities in adult patients undergoing cardiac surgery, were excluded. Most of the AKI suffered was likely a result of mild to moderate tubular injury. Only a few patients required dialysis.

However, there is a large discrepancy in the performance of NGAL as an early AKI biomarker between adult and pediatric AKI patients (Table 2). Parikh et al ${ }^{35,36}$ conducted a multicenter prospective cohort study of 1219 adults and 311 children undergoing cardiac surgery. The AUC-ROC for the prediction of AKI was rather disappointing for NGAL. The clinical prediction model for AKI had an AUC-ROC of 0.69, while uNGAL and pNGAL have AUC-ROC values of 0.67 and 0.70 , respectively, for adult AKI patients. Meanwhile, uNGAL and pNGAL have AUC-ROC values of 0.71 and 0.56 , respectively, for pediatric AKI patients. NGAL performed poorly for the early detection of AKI after surgery in this study. This finding is, however, similar to existing published studies among adult patients. In a single-center prospective study of 426 adult patients, uNGAL levels were increased within 1 hour of CPB and found to have AUC-ROC values of 0.60 at 3 hours and 0.61 at 18 hours after $\mathrm{CPB} .{ }^{37}$ Koyner et $\mathrm{al}^{38}$ also reported that $\mathrm{uNGAL}$ has an AUC-ROC value of $0.61-0.70$ at various time points after cardiac surgery in adult patients. Meanwhile, Haase-Fielitz et al reported that pNGAL had an AUC-ROC value of 0.80-0.87 for the prediction of AKI within 24 hours of cardiac surgery in adult patients. ${ }^{39}$ The reasons for this discrepancy are not completely clear.

NGAL also demonstrated as a predictor marker for AKI in both pediatric and adult critically ill patients (Table 2). NGAL was able to predict the development of AKI about 1-2 days prior to the increase in $\mathrm{SCr} .{ }^{40-44}$ Its AUC-ROC values were $0.68-0.78$ and $0.71-0.92$ among pediatric and adult critically ill patients, respectively. However, most of these studies were small and/or single-center studies. NGAL was also associated with a predictor of contrast-induced nephropathy (CIN) following IV contrast dye exposure in several small prospective studies of children and adults undergoing cardiac catheterization (Table 2). However, these studies were very limited because there were few cases of CIN without information on the severity and outcome of AKI ${ }^{45-47}$ Furthermore, there was no direct comparison of SCr with AKI biomarkers for the detection of CIN.

NGAL appears to be a more sensitive and specific AKI biomarker in pediatric patients. It is possible that a lack of standardization for the measurement of NGAL 
Table 2 Prospective studies of NGAL for early detection of AKI

\begin{tabular}{|c|c|c|c|c|}
\hline Clinical study & Study population & Type of study & Major findings & Limitations \\
\hline \multicolumn{5}{|l|}{ Cardiac surgery } \\
\hline Mishra et $\mathrm{al}^{33}$ & $\begin{array}{l}\text { Pediatric cardiac } \\
\text { surgery patients } \\
(n=7 I)\end{array}$ & $\begin{array}{l}\text { Prospective study } \\
\text { (uNGAL and pNGAL) }\end{array}$ & $\begin{array}{l}\text { AUC-ROC of } 0.99 \text { at } \\
2 \mathrm{hr} \text { after surgery }\end{array}$ & $\begin{array}{l}\text { Single center study } \\
\text { No patients with } \\
\text { severe AKI }\end{array}$ \\
\hline Dent et $\mathrm{al}^{26}$ & $\begin{array}{l}\text { Pediatric cardiac } \\
\text { surgery patients }(n=120)\end{array}$ & $\begin{array}{l}\text { Prospective study } \\
\text { (pNGAL) }\end{array}$ & $\begin{array}{l}\text { AUC-ROC of } 0.96 \text { at } \\
2 \mathrm{hr} \text { after surgery }\end{array}$ & Single center study \\
\hline Bennett et $\mathrm{a}^{27}$ & $\begin{array}{l}\text { Pediatric cardiac } \\
\text { surgery patients }(n=196)\end{array}$ & $\begin{array}{l}\text { Prospective study } \\
\text { (uNGAL) }\end{array}$ & $\begin{array}{l}\text { AUC-ROC of } 0.95 \text { at } \\
2 \mathrm{hr} \text { after surgery }\end{array}$ & Single center study \\
\hline Wagener et $\mathrm{al}^{37}$ & $\begin{array}{l}\text { Adult cardiac surgery } \\
\text { patients }(n=426)\end{array}$ & $\begin{array}{l}\text { Prospective study } \\
\text { (uNGAL) }\end{array}$ & $\begin{array}{l}\text { AUC-ROC of } 0.60,0.6 \mathrm{I} \text { and } \\
0.58 \text { at } 3 \mathrm{hr}, 18 \mathrm{hr}, 24 \mathrm{hr} \\
\text { after surgery, respectively }\end{array}$ & Single center study \\
\hline Koyner et al ${ }^{38}$ & $\begin{array}{l}\text { Adult cardiac surgery } \\
\text { patients }(n=72)\end{array}$ & $\begin{array}{l}\text { Prospective study } \\
\text { (uNGAL, pNGAL, } \\
\text { and others) }\end{array}$ & $\begin{array}{l}\text { AUC-ROC of } 0.6 \mathrm{I}-0.70 \text { and } \\
0.45-0.54 \text { at first } 6 \mathrm{hr} \text { after surgery } \\
\text { for UNGAL and PNGAL, } \\
\text { respectively }\end{array}$ & Single center study \\
\hline Haase-Fielitz et al ${ }^{39}$ & $\begin{array}{l}\text { Adult cardiac surgery } \\
\text { patients }(\mathrm{n}=100)\end{array}$ & $\begin{array}{l}\text { Prospective study } \\
\text { (pNGAL and others) }\end{array}$ & $\begin{array}{l}\text { AUC-ROC of } 0.8-0.89 \text { for NGAL } \\
\text { on arrival at ICU }\end{array}$ & Single center study \\
\hline Krawczeski et a ${ }^{34}$ & $\begin{array}{l}\text { Pediatric cardiac } \\
\text { surgery patients }(n=374)\end{array}$ & $\begin{array}{l}\text { Prospective study } \\
\text { (uNGAL and pNGAL) }\end{array}$ & $\begin{array}{l}\text { AUC-ROC of } 0.95 \text { at } 2 \mathrm{hr} \\
\text { after surgery }\end{array}$ & Single center study \\
\hline Parikh et al $\left.\right|^{35,36}$ & $\begin{array}{l}\text { Adult }(n=1219) \text { and } \\
\text { pediatric }(n=311) \\
\text { cardiac surgery patients }\end{array}$ & $\begin{array}{l}\text { Prospective multi- } \\
\text { centered study (uNGAL, } \\
\text { pNGAL, and others) }\end{array}$ & $\begin{array}{l}\text { AUC-ROC of } 0.67 \text { and } 0.70 \text { (adult) } \\
\text { and } 0.7 I \text { and } 0.56 \text { (children) for } \\
\text { uNGAL and PNGAL, respectively }\end{array}$ & \\
\hline \multicolumn{5}{|l|}{ Critical care } \\
\hline Zappitelli et a $\left.\right|^{40}$ & $\begin{array}{l}\text { Pediatric critically } \\
\text { ill patients }(n=140)\end{array}$ & $\begin{array}{l}\text { Prospective study } \\
\text { (uNGAL) }\end{array}$ & $\begin{array}{l}\text { AUC-ROC of } 0.78 \text { for predicting } \\
\text { AKI development within next } 48 \mathrm{hr}\end{array}$ & $\begin{array}{l}\text { Single center } \\
\text { study and small } \\
\text { sample size }\end{array}$ \\
\hline Wheeler et $\mathrm{a}^{41}$ & $\begin{array}{l}\text { Pediatric critically ill } \\
\text { patients with septic } \\
\text { shock }(n=168)\end{array}$ & $\begin{array}{l}\text { Prospective study } \\
\text { from I5 PICUs } \\
\text { (pNGAL) }\end{array}$ & $\begin{array}{l}\text { AUC-ROC of } 0.68 \text { for predicting } \\
\text { AKI development }\end{array}$ & $\begin{array}{l}\text { Small sample size } \\
\text { Control group } \\
\text { was from healthy } \\
\text { children }\end{array}$ \\
\hline Siew et $\mathrm{al}^{42}$ & $\begin{array}{l}\text { Adult critically ill } \\
\text { patients }(n=450)\end{array}$ & $\begin{array}{l}\text { Prospective study } \\
\text { (uNGAL) }\end{array}$ & $\begin{array}{l}\text { AUC-ROC of } 0.7 \mathrm{I} \text { and } 0.64 \\
\text { for predicting AKI development } \\
\text { within next } 24-48 \mathrm{hr}\end{array}$ & $\begin{array}{l}\text { Clinical model } \\
\text { has better } \\
\text { performance for } \\
\text { AKI prediction }\end{array}$ \\
\hline Constantin et a ${ }^{43}$ & $\begin{array}{l}\text { Adult critically ill } \\
\text { patients }(n=88)\end{array}$ & $\begin{array}{l}\text { Prospective study } \\
\text { (pNGAL) }\end{array}$ & $\begin{array}{l}\text { AUC-ROC of } 0.92 \text { for predicting } \\
\text { AKI development at ICU admission }\end{array}$ & $\begin{array}{l}32 \text { out of } 52 \mathrm{AKI} \\
\text { patients already } \\
\text { had elevated } \mathrm{SCr} \\
\text { at the time of ICU } \\
\text { admission }\end{array}$ \\
\hline Cruz et $\mathrm{al}^{44}$ & $\begin{array}{l}\text { Adult critically ill } \\
\text { patients }(n=30 I)\end{array}$ & $\begin{array}{l}\text { Prospective study } \\
\text { (pNGAL) }\end{array}$ & $\begin{array}{l}\text { AUC-ROC of } 0.78 \text { for predicting } \\
\mathrm{AKI} \text { development within next } 48 \mathrm{hr}\end{array}$ & Single center study \\
\hline \multicolumn{5}{|c|}{ Contrast induced nephropathy } \\
\hline $\begin{array}{l}\text { Bachorzewska- } \\
\text { Gajewska et } \mathrm{al}^{45}\end{array}$ & $\begin{array}{l}\text { Adult patients for } \\
\text { cardiac catheterization } \\
(\mathrm{n}=35)\end{array}$ & $\begin{array}{l}\text { Prospective } \\
\text { (uNGAL and } \\
\text { pNGAL) }\end{array}$ & $\begin{array}{l}\text { uNGAL and pNGAL were } \\
\text { elevated } 2-4 \mathrm{hr} \text { and } 4-12 \mathrm{hr} \\
\text { after IV contrast exposure }\end{array}$ & $\begin{array}{l}\text { Single center study } \\
\text { No episode of CIN }\end{array}$ \\
\hline Hirsch et al ${ }^{46}$ & $\begin{array}{l}\text { Pediatric patients for } \\
\text { cardiac catheterization } \\
(n=91)\end{array}$ & $\begin{array}{l}\text { Prospective } \\
\text { (uNGAL) }\end{array}$ & $\begin{array}{l}\text { uNGAL and pNGAL were } \\
\text { elevated } 2 \mathrm{hr} \text { after IV contrast } \\
\text { exposure, while SCr was elevated } \\
\text { in } 6-24 \mathrm{hr} \text { after IV contrast } \\
\text { exposure }\end{array}$ & $\begin{array}{l}\text { Single center study } \\
\text { No information } \\
\text { on severity and } \\
\text { outcome of CIN }\end{array}$ \\
\hline Malyszko et $\mathrm{al}^{47}$ & $\begin{array}{l}\text { Adult patients for } \\
\text { cardiac catheterization } \\
(n=140)\end{array}$ & $\begin{array}{l}\text { Prospective } \\
\text { (uNGAL, pNGAL, } \\
\text { and others) }\end{array}$ & $\begin{array}{l}\text { uNGAL and pNGAL were } \\
\text { elevated within } 4 \mathrm{hr} \text { after } \\
\text { IV contrast exposure }\end{array}$ & $\begin{array}{l}\text { Single center study } \\
\text { No informaiton } \\
\text { on severity and } \\
\text { outcome of } \mathrm{CIN}\end{array}$ \\
\hline
\end{tabular}

Abbreviations: AKI, acute kidney injury; AUC-ROC, area under the receiver operating characteristic curve; CIN, contrast-induced nephropathy; NGAL, neutrophil gelatinaseassociated lipocalin; pNGAL, plasma neutrophil gelatinase-associated lipocalin; uNGAL, urinary neutrophil gelatinase-associated lipocalin. 
and optimal methods for collecting, handling, and storing biological samples may contribute to the large discrepancy between studies. In addition, the ideal method for quantifying urinary AKI biomarkers has not yet been established. Normalization of urinary biomarker concentration to urine creatinine concentration can be inaccurate because of nonsteady states of creatinine balance in patients with AKI. Finally, the majority of published studies were from single centers that enrolled small numbers of patients and did not include patients with CKD. Such population studies are not representative of the global group of patients with AKI. Larger multi-center studies that are sufficiently powered are necessary to validate the role of biomarkers for the early detection of AKI.

\section{Kidney injury molecule-I}

Human KIM-1 is a type 1 transmembrane glycoprotein containing a novel 6-cysteine immunoglobulin-like domain and a threonine-/serine- and proline-rich domain characteristic of mucin-like O-glycosylated proteins. ${ }^{48} \mathrm{KIM}-1$ is also known as the hepatitis A virus cellular receptor 1 and T-cell immunoglobulin- and mucin-domain-containing molecule $1 .^{49,50}$ The KIM-1 family consists of eight members in mice, six in rats, and three in humans. ${ }^{51,52}$ The KIM-1 protein is not detectable in normal kidney tissue or urine but is expressed at high levels in dedifferentiated proximal tubule epithelial cells in human and rodent kidneys after ischemic or toxic injury, and in RCC. ${ }^{48,53-56}$

KIM-1 has been implicated as a urinary biomarker for postoperative AKI in pediatric and adult patients
(Table 3). ${ }^{29,57,58}$ AKI was defined as a 50\% increase in $\mathrm{SCr}$ occurring 1-3 days after surgery. uKIM-1 was increased within 2-12 hours after surgery and preceded an increase in SCr by $1-2$ days in patients who subsequently developed AKI. The AUC-ROC values ranged from 0.78 to 0.83 at various time points after surgery.

The heterogeneity of AKI suggests that more than one AKI marker may be necessary to obtain sufficient sensitivity and specificity for AKI screening. Han et $\mathrm{al}^{29}$ demonstrated that combining multiple urinary AKI biomarkers enhanced the sensitivity of the early detection of postoperative AKI compared to individual biomarkers. Different biomarkers reached peak levels at different time points after operation. How to combine multiple biomarkers at various time points for clinical use remains a challenge. Furthermore, additional urine collections are needed beyond the first 24 hours after surgery to study the temporal expression patterns of AKI biomarkers for late postoperative AKI.

In a small prospective study, uKIM-1 was associated as a predictor of CIN. Malyszko et $\mathrm{al}^{47}$ evaluated the utility of urinary biomarkers for the detection of CIN in 140 patients without CKD after cardiac catheterization. Seventeen patients developed CIN, which was defined as an increase in $\mathrm{SCr} \geq 25 \%$ of baseline within 48 hours of cardiac catheterization. uKIM-1 levels were increased at 24 and 48 hours post-catheterization for the CIN group, but without statistical significance. However, there is no information on the severity and outcome of CIN. Direct comparison of SCr with AKI biomarkers for the detection of AKI was not done. Overall, there have been no larger prospective multi-center studies to validate the temporal

Table 3 Prospective studies of KIM-I for early detection of AKI

\begin{tabular}{|c|c|c|c|c|}
\hline Clinical study & Study population & Type of study & Major findings & Limitations \\
\hline \multicolumn{5}{|c|}{ Cardiac surgery } \\
\hline Han et $\mathrm{al}^{57}$ & $\begin{array}{l}\text { Pediatric cardiac surgery } \\
\text { patients }(n=40)\end{array}$ & $\begin{array}{l}\text { Case control study } \\
\text { (uKIM-I and others) }\end{array}$ & $\begin{array}{l}\text { AUC-ROC of } 0.57,0.83 \\
\text { and } 0.78 \text { at } 2 \mathrm{hr}, 12 \mathrm{hr} \text { and } \\
24 \mathrm{hr}, \text { respectively }\end{array}$ & $\begin{array}{l}\text { Single center study and small } \\
\text { sample size. No patients } \\
\text { with severe AKI }\end{array}$ \\
\hline Han et $\mathrm{al}^{29}$ & $\begin{array}{l}\text { Adult cardiac surgery } \\
\text { patients }(\mathrm{n}=90)\end{array}$ & $\begin{array}{l}\text { Prospective study } \\
\text { (uKIM-I and others) }\end{array}$ & $\begin{array}{l}\text { AUC-ROC of } 0.75 \text { and } 0.78 \\
\text { at immediately and } 3 \mathrm{hr} \text { after } \\
\text { surgery for combing KIM-I, } \\
\text { NAG and NGAL }\end{array}$ & $\begin{array}{l}\text { Single center study and small } \\
\text { sample size. No standard } \\
\text { procedure to combine the } \\
\text { multiple biomarkers }\end{array}$ \\
\hline Liangos et $\mathrm{al}^{58}$ & $\begin{array}{l}\text { Adult cardiac surgery } \\
\text { patients }(n=103)\end{array}$ & $\begin{array}{l}\text { Prospective study } \\
\text { (uKIM-I and others) }\end{array}$ & $\begin{array}{l}\text { AUC-ROC of } 0.78 \text { at } 2 \mathrm{hr} \\
\text { after surgery }\end{array}$ & $\begin{array}{l}\text { Single center study and } \\
\text { small sample size }\end{array}$ \\
\hline \multicolumn{5}{|c|}{ Contrast induced nephropathy } \\
\hline Malyszko et al ${ }^{47}$ & $\begin{array}{l}\text { Adult patients for cardiac } \\
\text { catheterization }(n=140)\end{array}$ & $\begin{array}{l}\text { Prospective study } \\
\text { (uKIM-I and others) }\end{array}$ & $\begin{array}{l}\text { No statistically significant } \\
\text { KIM-I elevation in CIN group }\end{array}$ & $\begin{array}{l}\text { Single center study } \\
\text { No information on severity } \\
\text { and outcome of CIN }\end{array}$ \\
\hline
\end{tabular}

Abbreviations: AKI, acute kidney injury; AUC-ROC, area under the receiver operating characteristic curve; CIN, contrast-induced nephropathy; KIM-I, kidney injury molecule-I; NAG, N-acetyl- $\beta$-D-glucosaminidase; NGAL, neutrophil gelatinase-associated lipocalin; uKIM-I, urinary kidney injury molecule-I. 
expression patterns of uKIM-1 for the early detection of AKI, or to elucidate how this temporal course relates to the onset, severity, and outcome of AKI.

\section{Interleukin- 18}

IL-18 is a pro-inflammatory cytokine and has been shown to be involved in mediating inflammation in many organs. ${ }^{59-61}$ Renal IL-18 mRNA levels are significantly upregulated in the proximal tubules following ischemia-reperfusion injury, autoimmune nephritis, and cisplatin-induced nephrotoxicity. ${ }^{62}$ IL-18 is induced and cleaved in the proximal tubule, and can be detected in urine following ischemic AKI in animal models. ${ }^{63}$

The diagnostic utility of uIL-18 was evaluated for the early detection of postoperative AKI after pediatric cardiac surgery in a case control study, ${ }^{64}$ using samples from the same cohort in the NGAL study previously described. ${ }^{33}$ In that study, uNGAL was measured and found to have AUCROC values of 0.99 and 1.00 at 2 and 4 hours, respectively, following CPB. A subsequent study using all of the AKI cases and under half of the non-AKI cases showed that uIL-18 has AUC-ROC values of 0.61 at 4 hours, 0.75 at 12 hours, and 0.73 at 24 hours following CPB for the prediction of AKI (Table 4). Parikh et $\mathrm{al}^{35}$ reported that uIL-18 had an AUCROC value of 0.74 , while the clinical prediction model for AKI had an AUC-ROC value of 0.69 after cardiac surgery in adult patients. uIL-18 performed similarly for the early detection of AKI after cardiac surgery among pediatric patients. ${ }^{36}$ However, in a single-center prospective study of 100 adult patients, uIL-18 performed poorly, with an AUC-ROC value of $0.53-0.55$ at two time points after cardiac surgery. ${ }^{65}$

IL-18 also associated as a predictor biomarker for AKI in pediatric and adult critically ill patients (Table 4). In a prospective study of 138 patients with acute respiratory distress syndrome, elevated uIL-18 levels in the AKI group preceded the elevation of SCr by 1-2 days, with an AUC-ROC value of 0.73 , and was an independent predictor of death in this cohort. ${ }^{66}$ Washburn et $\mathrm{al}^{67}$ also demonstrated among pediatric patients that uIL-18 was elevated about 2 days prior to the rise in SCr, but that the AUC-ROC value was 0.54 for predicting AKI development within 24 hours.

Overall, there have been very few studies done to validate the temporal expression patterns of uIL-18 for the early detection of AKI, or to elucidate how this temporal course relates to the onset, severity, and outcome of AKI.

\section{Conclusion}

The ultimate goal of a more sensitive AKI biomarker or panel of AKI biomarkers is improved early detection and monitoring of AKI, which will lead to improved outcomes through earlier therapeutic intervention and the re-evaluation of other pharmacologic agents that have shown promise in experimental animal models. The search for new AKI biomarkers has been evolving rapidly with advancements in modern technologies. Recently, several protein biomarkers, including KIM-1, NGAL, IL-18, cystatin C, and L-fatty acid binding protein, have emerged through the application of functional genomics and proteomics to human and ani-

Table 4 Prospective studies of IL- 18 for early detection of AKI

\begin{tabular}{|c|c|c|c|c|}
\hline Clinical study & Study population & Type of study & Major findings & Limitations \\
\hline \multicolumn{5}{|l|}{ Cardiac surgery } \\
\hline Parikh et al ${ }^{64}$ & $\begin{array}{l}\text { Pediatric cardiac surgery } \\
\text { patients }(n=55)\end{array}$ & $\begin{array}{l}\text { Prospective } \\
\text { study (ulL-I8) }\end{array}$ & $\begin{array}{l}\text { AUC-ROC of } 0.6 \mathrm{I}, 0.75,0.73 \\
\text { at } 4 \mathrm{hr}, \mathrm{I} 2 \mathrm{hr} \text {, and } 24 \mathrm{hr} \text { after } \\
\text { surgery, respectively }\end{array}$ & $\begin{array}{l}\text { Single center study } \\
\text { and small sample size }\end{array}$ \\
\hline Haase et $\mathrm{a}^{165}$ & $\begin{array}{l}\text { Adult cardiac surgery } \\
\text { patients }(\mathrm{n}=100)\end{array}$ & $\begin{array}{l}\text { Prospective } \\
\text { study (ulL-I8) }\end{array}$ & $\begin{array}{l}\text { AUC-ROC of } 0.53 \text { at arrival } \\
\text { to ICU after surgery }\end{array}$ & $\begin{array}{l}\text { Single center study } \\
\text { and small sample size }\end{array}$ \\
\hline Parikh et a $\left.\right|^{35,36}$ & $\begin{array}{l}\text { Adult }(n=1219) \text { and } \\
\text { pediatric }(n=311) \\
\text { cardiac surgery patients }\end{array}$ & $\begin{array}{l}\text { Prospective } \\
\text { multi-centered study } \\
\text { (ulL-18 and others) }\end{array}$ & $\begin{array}{l}\text { AUC-ROC of } 0.74 \text { (adult) } \\
\text { and } 0.72 \text { (children), } \\
\text { respectively }\end{array}$ & \\
\hline \multicolumn{5}{|l|}{ Critical care } \\
\hline Parikh et al ${ }^{66}$ & $\begin{array}{l}\text { Adult critically ill } \\
\text { patients }(n=138)\end{array}$ & $\begin{array}{l}\text { Prospective } \\
\text { study (ulL-I8) }\end{array}$ & $\begin{array}{l}\text { AUC-ROC of } 0.73 \\
\text { for predicting AKI } \\
\text { development within } 24 \mathrm{hr}\end{array}$ & $\begin{array}{l}\text { Excluded } 479 \text { out } \\
\text { of } 617 \text { patients in } \\
\text { ARDS network trial }\end{array}$ \\
\hline Washburn et al ${ }^{67}$ & $\begin{array}{l}\text { Pediatric critically } \\
\text { ill patients }(n=137)\end{array}$ & $\begin{array}{l}\text { Prospective } \\
\text { study (ulL-I8) }\end{array}$ & $\begin{array}{l}\text { AUC-ROC of } 0.54 \\
\text { for predicting AKI } \\
\text { development within } 24 \mathrm{hr}\end{array}$ & $\begin{array}{l}\text { Single center study } \\
\text { and small sample size }\end{array}$ \\
\hline
\end{tabular}

Abbreviations: AKI, acute kidney injury; ARDS, acute respiratory distress syndrome; AUC-ROC, area under the receiver operating characteristic curve; ICU, intensive care unit; IL-18, interleukin-18; ulL-18, urinary interleukin-18. 
mal AKI models. However, several requirements must be met for their use in daily clinical practice. AKI biomarkers must ideally allow for the early detection of kidney injury, identify the severity of the AKI, provide a rationale for risk stratification for clinical studies including the identification of patients at risk for AKI, guide the timing of therapy, reflect the improvement and worsening of the kidney injury, and be amenable to quick and reliable measurement at the bedside or in the clinical laboratory.

Available studies have highlighted several limitations of new AKI biomarkers in the early detection and prediction of AKI; these limitations preclude the mainstream acceptance of AKI biomarkers in the clinical setting. Most of the human studies come from single centers and from homogeneous patient populations. Most studies assessing AKI exclude CKD patients. Most AKI cases were not severe injuries based on the rapid reversibility of $\mathrm{SCr}$, and only a limited number of AKI patients required RRT. Existing studies have been insufficiently powered to establish a cutoff value that is predictive of AKI, especially with severe injury. There is presently limited data available regarding the utility of biomarkers for differentiating causes of AKI. Furthermore, the heterogeneity of AKI and existing published data suggest that more than one biomarker may be necessary to obtain sufficient sensitivity and specificity for the early detection of AKI. There is emerging evidence that combining multiple biomarkers may allow for the early detection of AKI. ${ }^{29,57}$ However, there is currently no standard way to combine multiple biomarkers for clinical use. It also remains unclear if combining biomarkers will provide a sufficiently high sensitivity to provide clinically useful, predictive information over the use of SCr alone.

Larger prospective multicenter studies are absolutely necessary to validate the temporal expression patterns of various AKI biomarkers for the early detection of AKI, and to elucidate how this temporal course relates to the onset, severity, and outcome of AKI. However, the evaluation of the performance of AKI biomarkers is inherently flawed because there is currently no standard definition of AKI that is not based on a change in SCr. The use of an imperfect $\mathrm{SCr}$ in the authors' definition of AKI can lead to poor performance by AKI biomarkers. ${ }^{68}$ The main question, then, is how to define the AKI without depending on SCr. One possible option is to define the AKI based on the profile of multiple biomarkers that are sensitive to renal tubular injury. However, this approach needs further study to address several issues. First, we need a histopathologic evaluation of the kidney in order to directly relate the biomarkers to injury, but routine renal biopsy in AKI patients is not feasible, and there can be dissociation between structural changes and functional decreases in AKI. Second, we need to investigate the clinical relevance of subclinical alterations in renal function detected by urinary biomarkers without overt changes in $\mathrm{SCr}^{69-72}$ So far there have been no pathologic evaluations of the kidney among patients with subclinical AKI. Third, more information must be gathered regarding the accuracy of biomarker measurements in the presence of interfering substances and the stability of the various biomarkers in routine clinical storage conditions, including a number of freeze-thaw cycles. Fourth, it is known that the measurements of AKI biomarkers can be influenced by systemic inflammation, infection, the patient's age, malignancy, and CKD. Finally, we need standardization for the measurement of biomarkers. Until a better AKI definition is available, we continue to be cautious of interpretations of reported AKI biomarkers' performance.

Once a more sensitive biomarker or panel of biomarkers for AKI is validated for clinical use, the next challenging tasks are the development of a POC and the selection of a suitable patient group for pharmacologic treatment. POC will provide a quick and reliable measurement at the bedside or in clinical laboratory for the detection of AKI. Multiple therapeutic possibilities that showed promise in animal studies but failed in human studies can then be revisited in clinical trials. However, it is critical to know the timing of the kidney insult because previous animal studies and failed attempts of human intervention in clinical trials clearly demonstrate that the introduction of treatment should precede the rise of $\mathrm{SCr}$ and be very early after the insult. This will greatly limit the utility of AKI biomarkers and potential pharmacologic treatments to patients with hospitalized AKI, including postoperative or contrast-dye-induced AKI.

Despite the early promise of new AKI biomarkers for the early detection of AKI, there is no clear evidence that current AKI biomarkers demonstrate a clear benefit over traditional approaches in clinical decision-making in patients with AKI. More studies with better biomarkers are required to establish their utility in daily clinical practice.

\section{Disclosure}

The author reports no conflicts of interest in this work.

\section{References}

1. Chertow GM, Lee J, Kuperman GJ, et al. Guided medication dosing for inpatients with renal insufficiency. JAMA. 2001;286(22):2839-2844. 
2. Liangos O, Wald R, O'Bell JW, Price L, Pereira BJ, Jaber BL. Epidemiology and outcomes of acute renal failure in hospitalized patients: a national survey. Clin J Am Soc Nephrol. 2006;1(1):43-51.

3. Zanardo G, Michielon P, Paccagnella A, et al. Acute renal failure in the patient undergoing cardiac operation. Prevalence, mortality rate, and main risk factors. J Thorac Cardiovasc Surg. 1994;107(6): 1489-1495.

4. Uchino S, Kellum JA, Bellomo R, et al. Acute renal failure in critically ill patients: a multinational, multicenter study. JAMA. 2005;294(7):813-818.

5. Bellomo R, Ronco C, Kellum JA, Mehta RL, Palevsky P; Acute Dialysis Quality Initiative Workgroup. Acute renal failure - definition, outcome measures, animal models, fluid therapy and information technology needs: the Second International Consensus Conference of the Acute Dialysis Quality Initiative (ADQI) Group. Crit Care. 2004;8(4):R204-R212.

6. Mehta RL, Kellum JA, Shah SV, et al. Acute Kidney Injury Network: report of an initiative to improve outcomes in acute kidney injury. Crit Care. 2007;11(2):R31.

7. Bellomo R, Kellum J, Ronco C. Acute renal failure: time for consensus. Intensive Care Med. 2001;27(11):1685-1688.

8. Devarajan P. Update on mechanisms of ischemic acute kidney injury. J Am Soc Nephrol. 2006;17(6):1503-1520.

9. Murray PT, Devarajan P, Levey AS, et al. A framework and key research questions in AKI diagnosis and staging in different environments. Clin J Am Soc Nephrol. 2008;3(3):864-868.

10. Lieberthal W, Sheridan AM, Valeri CR. Protective effect of atrial natriuretic factor and mannitol following renal ischemia. Am J Physiol. 1990;258(5 Pt 2):F1266-F1272.

11. Conger JD, Falk SA, Hammond WS. Atrial natriuretic peptide and dopamine in established acute renal failure in the rat. Kidney Int. 1991;40(1):21-28.

12. Miller SB, Martin DR, Kissane J, Hammerman MR. Rat models for clinical use of insulin-like growth factor I in acute renal failure. Am J Physiol. 1994;266(6 Pt 2):F949-F956.

13. Kelly KJ, Tolkoff-Rubin NE, Rubin RH, et al. An oral platelet-activating factor antagonist, Ro-24-4736, protects the rat kidney from ischemic injury. Am J Physiol. 1996;271(5 Pt 2):F1061-F1067.

14. Chiao H, Kohda Y, McLeroy P, Craig L, Housini I, Star RA. Alphamelanocyte-stimulating hormone protects against renal injury after ischemia in mice and rats. J Clin Invest. 1997;99(6):1165-1172.

15. Allgren RL, Marbury TC, Rahman SN, et al. Anaritide in acute tubular necrosis. Auriculin Anaritide Acute Renal Failure Study Group. N Engl J Med. 1997;336(12):828-834.

16. Hirschberg R, Kopple J, Lipsett P, et al. Multicenter clinical trial of recombinant human insulin-like growth factor I in patients with acute renal failure. Kidney Int. 1999;55(6):2423-2432.

17. Wang A, Holcslaw T, Bashore TM, et al. Exacerbation of radiocontrast nephrotoxicity by endothelin receptor antagonism. Kidney Int. 2000;57(4):1675-1680.

18. Lewis J, Salem MM, Chertow GM, et al. Atrial natriuretic factor in oliguric acute renal failure. Anaritide Acute Renal Failure Study Group. Am J Kidney Dis. 2000;36(4):767-774.

19. Bove T, Landoni G, Calabrò MG, et al. Renoprotective action of fenoldopam in high-risk patients undergoing cardiac surgery: a prospective, double-blind, randomized clinical trial. Circulation. 2005;111(24):3230-3235.

20. Han WK, Bonventre JV. Biologic markers for the early detection of acute kidney injury. Curr Opin Crit Care. 2004;10(6):476-482.

21. Vaidya VS, Ferguson MA, Bonventre JV. Biomarkers of acute kidney injury. Annu Rev Pharmacol Toxicol. 2008;48:463-493.

22. Parikh CR, Devarajan P. New biomarkers of acute kidney injury. Crit Care Med. 2008;36(Suppl 4):S159-S165.

23. Devarajan P. Biomarkers for the early detection of acute kidney injury. Curr Opin Pediatr. 2011;23(2):194-200.
24. Schiffl H, Lang SM. Update on biomarkers of acute kidney injury: moving closer to clinical impact? Mol Diagn Ther. 2012;16(4):199-207.

25. Shaw A. Update on acute kidney injury after cardiac surgery. J Thorac Cardiovasc Surg. 2012;143(3):676-681.

26. Dent CL, Ma Q, Dastrala S, et al. Plasma neutrophil gelatinase-associated lipocalin predicts acute kidney injury, morbidity and mortality after pediatric cardiac surgery: a prospective uncontrolled cohort study. Crit Care. 2007;11(6):R127.

27. Bennett M, Dent CL, Ma Q, et al. Urine NGAL predicts severity of acute kidney injury after cardiac surgery: a prospective study. Clin J Am Soc Nephrol. 2008;3(3):665-673.

28. Vaidya VS, Ford GM, Waikar SS, et al. A rapid urine test for early detection of kidney injury. Kidney Int. 2009;76(1):108-114.

29. Han WK, Wagener G, Zhu Y, Wang S, Lee HT. Urinary biomarkers in the early detection of acute kidney injury after cardiac surgery. Clin J Am Soc Nephrol. 2009;4(5):873-882.

30. Flower DR, North AC, Sansom CE. The lipocalin protein family: structural and sequence overview. Biochim Biophys Acta. 2000; 1482(1-2):9-24.

31. Mishra J, Ma Q, Prada A, et al. Identification of neutrophil gelatinaseassociated lipocalin as a novel early urinary biomarker for ischemic renal injury. J Am Soc Nephrol. 2003;14(10):2534-2543.

32. Schmidt-Ott KM, Mori K, Li JY, et al. Dual action of neutrophil gelatinaseassociated lipocalin. J Am Soc Nephrol. 2007;18(2):407-413.

33. Mishra J, Dent C, Tarabishi R, et al. Neutrophil gelatinase-associated lipocalin (NGAL) as a biomarker for acute renal injury after cardiac surgery. Lancet. 2005;365(9466):1231-1238.

34. Krawczeski CD, Woo JG, Wang Y, Bennett MR, Ma Q, Devarajan P. Neutrophil gelatinase-associated lipocalin concentrations predict development of acute kidney injury in neonates and children after cardiopulmonary bypass. J Pediatr. 2011;158(6):1009-1015.

35. Parikh CR, Coca SG, Thiessen-Philbrook H, et al. Postoperative biomarkers predict acute kidney injury and poor outcomes after adult cardiac surgery. J Am Soc Nephrol. 2011;22(9):1748-1757.

36. Parikh CR, Devarajan P, Zappitelli M, et al. Postoperative biomarkers predict acute kidney injury and poor outcomes after pediatric cardiac surgery. J Am Soc Nephrol. 2011;22(9):1737-1747.

37. Wagener G, Gubitosa G, Wang S, Borregaard N, Kim M, Lee HT. Urinary neutrophil gelatinase-associated lipocalin and acute kidney injury after cardiac surgery. Am J Kidney Dis. 2008;52(3):425-433.

38. Koyner JL, Bennett MR, Worcester EM, et al. Urinary cystatin C as an early biomarker of acute kidney injury following adult cardiothoracic surgery. Kidney Int. 2008;74(8):1059-1069.

39. Haase-Fielitz A, Bellomo R, Devarajan P, et al. Novel and conventional serum biomarkers predicting acute kidney injury in adult cardiac surgery - a prospective cohort study. Crit Care Med. 2009;37(2): 553-560.

40. Zappitelli M, Washburn KK, Arikan AA, et al. Urine neutrophil gelatinase-associated lipocalin is an early marker of acute kidney injury in critically ill children: a prospective cohort study. Crit Care. 2007; 11(4):R84.

41. Wheeler DS, Devarajan P, Ma Q, et al. Serum neutrophil gelatinaseassociated lipocalin (NGAL) as a marker of acute kidney injury in critically ill children with septic shock. Crit Care Med. 2008;36(4):1297-1303.

42. Siew ED, Ware LB, Gebretsadik T, et al. Urine neutrophil gelatinaseassociated lipocalin moderately predicts acute kidney injury in critically ill adults. J Am Soc Nephrol. 2009;20(8):1823-1832.

43. Constantin JM, Futier E, Perbet S, et al. Plasma neutrophil gelatinaseassociated lipocalin is an early marker of acute kidney injury in adult critically ill patients: a prospective study. J Crit Care. 2010;25(1): 176.e1-176.e6.

44. Cruz DN, de Cal M, Garzotto F, et al. Plasma neutrophil gelatinaseassociated lipocalin is an early biomarker for acute kidney injury in an adult ICU population. Intensive Care Med. 2010;36(3):444-451. 
45. Bachorzewska-Gajewska H, Malyszko J, Sitniewska E, Malyszko JS, Dobrzycki S. Neutrophil gelatinase-associated lipocalin (NGAL) correlations with cystatin $\mathrm{C}$, serum creatinine and eGFR in patients with normal serum creatinine undergoing coronary angiography. Nephrol Dial Transplant. 2007;22(1):295-296.

46. Hirsch R, Dent C, Pfriem H, et al. NGAL is an early predictive biomarker of contrast-induced nephropathy in children. Pediatr Nephrol. 2007;22(12):2089-2095.

47. Malyszko J, Bachorzewska-Gajewska H, Poniatowski B, Malyszko JS, Dobrzycki S. Urinary and serum biomarkers after cardiac catheterization in diabetic patients with stable angina and without severe chronic kidney disease. Ren Fail. 2009;31(10):910-919.

48. Ichimura T, Bonventre JV, Bailly V, et al. Kidney Injury Molecule-1 (KIM-1), a putative epithelial cell adhesion molecule containing a novel immunoglobulin domain, is up-regulated in renal cells after injury. J Biol Chem. 1998;273(7):4135-4142.

49. Feigelstock D, Thompson P, Mattoo P, Kaplan GG. Polymorphisms of the hepatitis A virus cellular receptor 1 in African green monkey kidney cells result in antigenic variants that do not react with protective monoclonal antibody 190/4. J Virol. 1998;72(7):6218-6222.

50. Kuchroo VK, Umetsu DT, DeKruyff RH, Freeman GJ. The TIM gene family: emerging roles in immunity and disease. Nat Rev Immunol. 2003;3(6):454-462.

51. Meyers JH, Sabatos CA, Chakravarti S, Kuchroo VK. The TIM gene family regulates autoimmune and allergic diseases. Trends $\mathrm{Mol} \mathrm{Med.}$ 2005;11(8):362-369.

52. Kuchroo VK, Meyers JH, Umetsu DT, DeKruyff RH. TIM family of genes in immunity and tolerance. Adv Immunol. 2006;91:227-249.

53. Ichimura T, Hung CC, Yang SA, Stevens JL, Bonventre JV. Kidney injury molecule-1: a tissue and urinary biomarker for nephrotoxicant-induced renal injury. Am J Physiol Renal Physiol. 2004;286(3):F552-F563.

54. Han WK, Bailly V, Abichandani R, Thadhani R, Bonventre JV. Kidney injury molecule-1 (KIM-1): A novel biomarker for human renal proximal tubule injury. Kidney Int. 2002;62(1):237-244.

55. Han WK, Alinani A, Wu CL, et al. Human kidney injury molecule-1 is a tissue and urinary tumor marker of renal cell carcinoma. J Am Soc Nephrol. 2005;16(4):1126-1134.

56. Lin F, Zhang PL, Yang XJ, et al. Human kidney injury molecule-1 (hKIM-1): a useful immunohistochemical marker for diagnosing renal cell carcinoma and ovarian clear cell carcinoma. Am J Surg Pathol. 2007;31(3):371-381

57. Han WK, Waikar SS, Johnson A, et al. Urinary biomarkers in the early diagnosis of acute kidney injury. Kidney Int. 2008;73(7):863-869.

58. Liangos $\mathrm{O}$, Tighiouart $\mathrm{H}$, Perianayagam MC, et al. Comparative analysis of urinary biomarkers for early detection of acute kidney injury following cardiopulmonary bypass. Biomarkers. 2009;14(6):423-431.
59. Jordan JA, Guo RF, Yun EC, et al. Role of IL-18 in acute lung inflammation. J Immunol. 2001;167(12):7060-7068.

60. Pomerantz BJ, Reznikov LL, Harken AH, Dinarello CA. Inhibition of caspase 1 reduces human myocardial ischemic dysfunction via inhibition of IL-18 and IL-1beta. Proc Natl Acad Sci U S A. 2001;98(5): 2871-2876.

61. Hedtjärn M, Leverin AL, Eriksson K, Blomgren K, Mallard C, Hagberg H. Interleukin-18 involvement in hypoxic-ischemic brain injury. J Neurosci. 2002;22(14):5910-5919.

62. Leslie JA, Meldrum KK. The role of interleukin-18 in renal injury. J Surg Res. 2008;145(1):170-175.

63. Melnikov VY, Ecder T, Fantuzzi G, et al. Impaired IL-18 processing protects caspase-1-deficient mice from ischemic acute renal failure. J Clin Invest. 2001;107(9):1145-1152.

64. Parikh CR, Mishra J, Thiessen-Philbrook H, et al. Urinary IL-18 is an early predictive biomarker of acute kidney injury after cardiac surgery. Kidney Int. 2006;70(1):199-203.

65. Haase M, Bellomo R, Story D, Davenport P, Haase-Fielitz A. Urinary interleukin-18 does not predict acute kidney injury after adult cardiac surgery: a prospective observational cohort study. Crit Care. 2008;12(4):R96.

66. Parikh CR, Abraham E, Ancukiewicz M, Edelstein CL. Urine IL-18 is an early diagnostic marker for acute kidney injury and predicts mortality in the intensive care unit. J Am Soc Nephrol. 2005;16(10):3046-3052.

67. Washburn KK, Zappitelli M, Arikan AA, et al. Urinary interleukin-18 is an acute kidney injury biomarker in critically ill children. Nephrol Dial Transplant. 2008;23(2):566-572.

68. Waikar SS, Betensky RA, Emerson SC, Bonventre JV. Imperfect gold standards for kidney injury biomarker evaluation. J Am Soc Nephrol. 2012;23(1):13-21.

69. Hamada Y, Kanda T, Anzai T, Kobayashi I, Morishita Y. N-acetyl-betaD-glucosaminidase is not a predictor, but an indicator of kidney injury in patients with cardiac surgery. J Med. 1999;30(5-6):329-336.

70. Boldt J, Brenner T, Lang J, Kumle B, Isgro F. Kidney-specific proteins in elderly patients undergoing cardiac surgery with cardiopulmonary bypass. Anesth Analg. 2003;97(6):1582-1589.

71. Provenchère S, Plantefève G, Hufnagel G, et al. Renal dysfunction after cardiac surgery with normothermic cardiopulmonary bypass: incidence, risk factors, and effect on clinical outcome. Anesth Analg 2003;96(5):1258-1264.

72. Haase M, Devarajan P, Haase-Fielitz A, et al. The outcome of neutrophil gelatinase-associated lipocalin-positive subclinical acute kidney injury: a multicenter pooled analysis of prospective studies. J Am Coll Cardiol. 2011;57(17):1752-1761.
Current Biomarker Findings

\section{Publish your work in this journal}

Current Biomarker Findings is an international, peer-reviewed, open access journal publishing original research, reports, reviews and commentaries on all areas of biomarker research. The manuscript management system is completely online and includes a very quick and fair

\section{Dovepress}

peer-review system. Visit http://www.dovepress.com/testimonials.php to read real quotes from published authors. 